\title{
The role of planted forests in improving the productive capacity and ecological potential of Scots pine boreal forests in the Middle Volga Region
}

\author{
Evgeny M. Romanov, Tatiana V. Nureeva ${ }^{*}$ and Nikolay V. Eremin
}

\begin{abstract}
Background: Russia's boreal forests are a major source of timber as well as being a large terrestrial sink for carbon. Planted forests have played an important role in increasing the overall area of the Russian boreal forest. The total area of planted stands in republics and oblasts of the Middle Volga Region is about 3.2 million ha. Scots pine (Pinus sylvestris L.) is the most widespread species in planted forests of the Middle Volga Region. As a result of its mass planting since the 1950s, the proportion of pine forests increased from 21 to $29 \%$. In order to justify the continued use of artificial regeneration to re-establish forests after harvest, more information is required on the growth and yield of planted and natural Scots pine forests. Therefore, the main objective of this study was to quantify and compare the productivity of planted Scots pine forests with that of natural forests in the Middle Volga Region.

Methods: Data were obtained from seven representative forests in the republics and oblasts of the Middle Volga Region spanning the period between 1961 and 2007. The relationship between total standing volume and stand age was modelled for both planted and natural stands of Scots pine using the nonlinear Mitscherlich equation.

Results: Planted Scots pine forests generally have a higher relative stand density than natural forests, due to the presence of natural regeneration in planted stands. Mean annual volume increment of planted Scots pine forests was $5.6-9.2 \mathrm{~m}^{3} / \mathrm{ha}$, which is approximately $15 \%$ greater than the volume increment of natural Scots pine forests.

Conclusions: Artificial stands are of high importance for maintenance of resource potential of Russian boreal forests. Mathematical and statistic calculations show benefits of planted Scots pine in comparison with natural pines in height, volume, density, productivity and growing stock increment. The achieved results suggest that wood can be obtained at an earlier age from planted forests thus preserving natural boreal forests.
\end{abstract}

Keywords: Scots pine, Planted forest, Natural forest, Restoration, Boreal forests

\section{Background}

Two thirds of all boreal forests globally grow in the territory of Russia (Olsson, 2009). In addition to providing a source of timber, they play a crucial role in sequestering carbon. The utility of boreal forests in effectively absorbing carbon dioxide provides an incentive to preserve and restore these valuable forest ecosystems in a sustainable manner. Planting is an important method of forest rehabilitation, and planted forests have a special importance

\footnotetext{
* Correspondence: maransh@yandex.ru; nureevatv@volgatech.net
} Volga State University of Technology, Yoshkar-Ola, Russia in the Middle Volga Region, which is a region of active forest management.

The Middle Volga Region is located between $54^{\circ}$ and $58^{\circ} \mathrm{N}$ and between $44^{\circ}$ and $52^{\circ} \mathrm{E}$ and encompasses territories adjacent to the Volga Region in the European part of Russia (Fig. 1). These include the Republic of Mari El, the Chuvash Republic, the Republic of Tatarstan and the Nizhny Novgorod oblast. ${ }^{1}$ The total area of the Middle Volga Region is more than $360,000 \mathrm{~km}^{2}$, of which natural and planted forests cover about $36.5 \%$. Within this region, there are areas with different climatic zones as well as different soil and ecological conditions. 


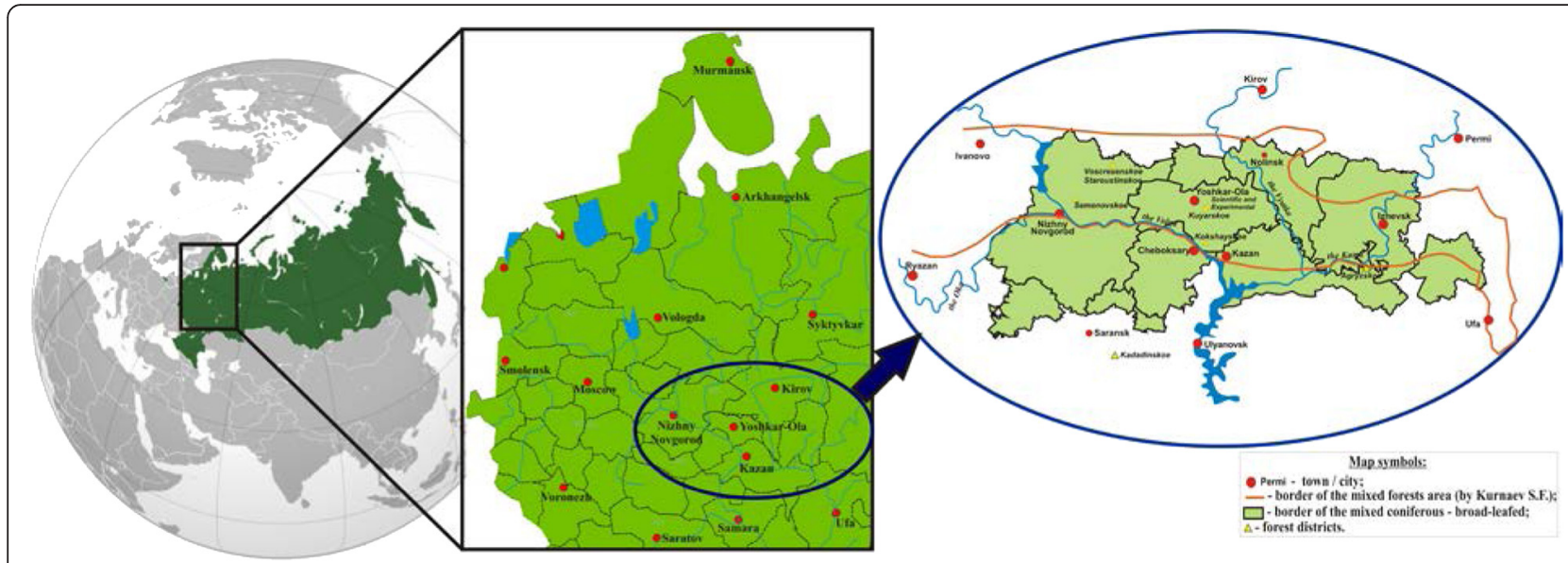

Fig. 1 Location of the Middle Volga Region within the Russian Federation

The climate of the Middle Volga Region is classified as a warm summer subzone of the mid-latitude zone. It is moderately continental with warm summers, moderately cold winters and relative humidity between 50 and $70 \%$. The temperature is below freezing for a long period each year and snow cover is typical. Mean annual air temperature in the region varies from 1.1 to $3.0{ }^{\circ} \mathrm{C}$. The average number of days per year when the temperature is above $+10{ }^{\circ} \mathrm{C}$ is approximately $110-130$. Forest species composition varies, but boreal forest with coniferous species (pines, spruces and larches) dominates. A quarter of Russian-planted forests are currently established in the Middle Volga Region, with Scots pine (Pinus sylvestris L.) and Norway spruce (Picea abies (L.) H. Karst.) as the most widespread species. The Scots pine planted in The Middle Volga Region boreal forests accounts for $8 \%$ in the Kirov Region to $32.5 \%$ in the Chuvash Republic of the area of all pine forests (both planted and natural). Norway spruce is a less common species for planted forests but $60 \%$ of Norway spruce forests are planted.

The forest communities of the Middle Volga Region are not high in biodiversity but are dominated by species that grow quickly and that naturally reproduce. The species composition of forests in the Middle Volga Region has changed since the 1950s mostly due to clearance of large areas of natural forest aimed at restoring the national economy after the Second World War. This issue affects spruce forests, in particular, as they grow in more fertile soils. Silver birch (Betula pendula Roth) is an early coloniser of bare ground so the forest area in this species increased from $17 \%$ in 1942 to $23 \%$ in 2007. The area of Scots pine plantations increased from $21 \%$ in 1942 to $29 \%$ in 2007 in four republics and oblasts of the Middle Volga Region (the Nizhny Novgorod oblast, the Republic of Mari El, the Chuvash Republic and the Republic of
Tatarstan). Over a 65-year period, the overall proportion of coniferous forest remained the same due to reforestation work and timely planting of seedlings.

Cultivation of softwood trees is a long, complex and costly process in boreal and temperate zones. Dry periods in spring and summer, competition from hardwoods, susceptibility to diseases and pests attacks and forest fires are the main risks for cultivation of planted forests. Despite these risks, planted forests make an important contribution to the Russian boreal forest resource. The total area of forests in the Middle Volga Region increased 12-23-fold during the last 65 years, and it is important to note that planted forests have played an important role in this increase (Romanov, Eremin \& Nureeva 2009). The area of planted forests has increased 6-7.5-fold during this period. Thus, it is possible to trace changes in forests over time. The Republic of Mari El is used as an example in Fig. 2 (Romanov, Eremin, Nureeva \& Mamaev 2008; Romanov, Eremin \& Nureeva 2013). The amount of un-forested land has reduced by a factor of 12.4 over the last 80 years. In the 40-year period from 1927 until 1966, there were only 70,000 ha of planted stands in the region but, in the following 40 years, the area of planted forests tripled. Most of the planted forests contain pines with smaller areas of other species, including Norway spruce, tillet (Tilia cordata Mill.), oak (Quercus robur L.), silver birch, aspen (Populus tremuloides Michx.) and Siberian fir (Abies sibirica Ledeb.) (Romanov, Eremin, Nureeva \& Mamaev 2008).

Intensive forest management is one of characteristic features of the Middle Volga Region. Comparison of Russian forest management with forest management in Finland is provided in Table 1. There is an on-going need for timber, and consequently, there are a number of large wood processing enterprises in the Middle Volga 


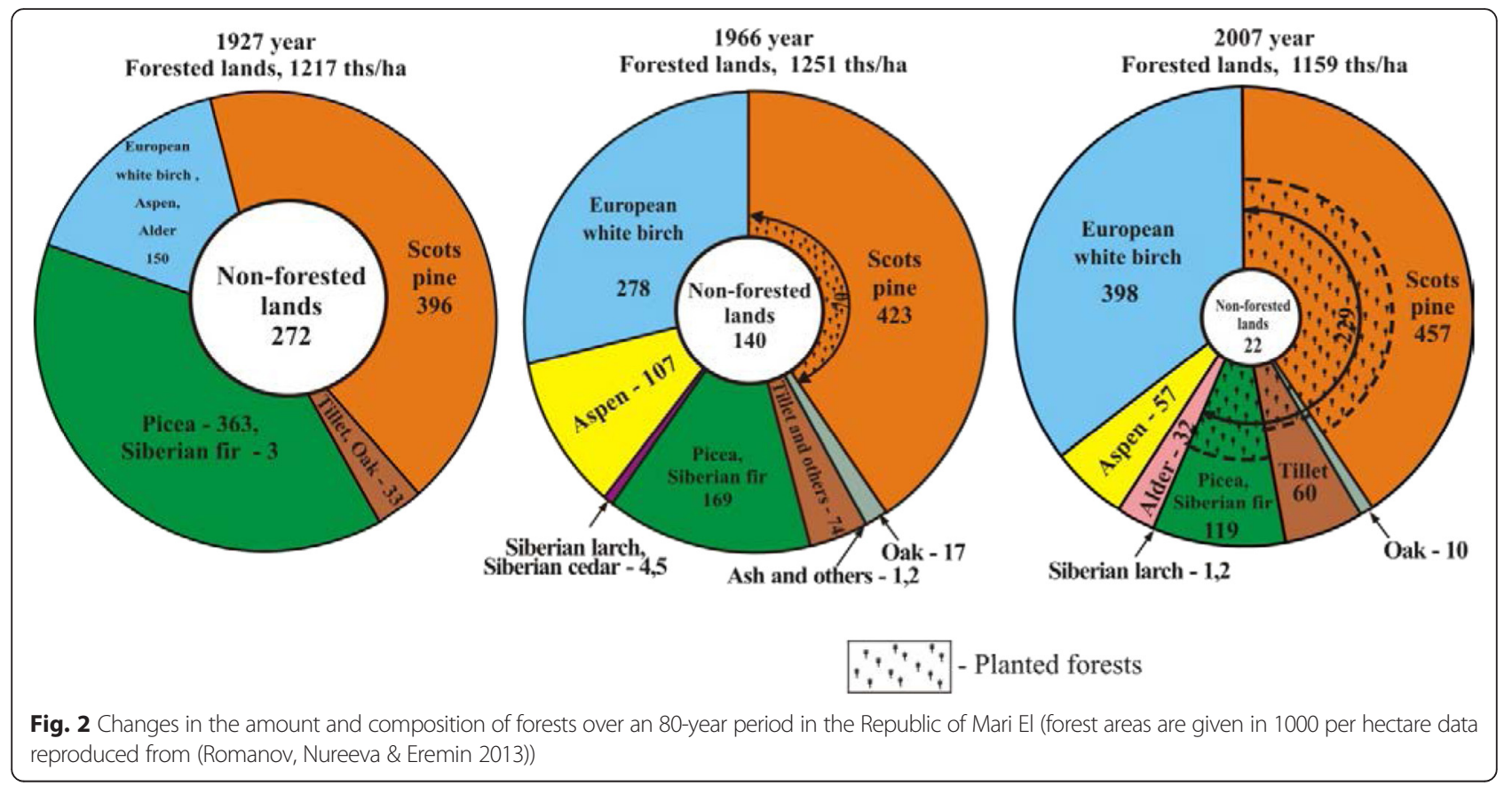

Region. There is considerable experience in artificial regeneration of non-forested areas in the Middle Volga Region, such that $25 \%$ of Russian-planted forests are established in this region. The proportion of planted forests in different republics and oblasts of the Middle Volga Region varies from 8 to $32 \%$. It is important to note that the proportion of planted forests is lower in northern regions and greater in southern regions (Fig. 3). Like natural boreal forests, planted forests perform the functions of carbon storage and maintain carbon balance in the atmosphere.

The problem of choosing the most appropriate method of forest regeneration is still a focus for many researchers and experts. One group of authors (e.g. Sennov, 1999; Denisov 1984, Denisov et al. 2002, 2011; Demakov et al. 2008; Kalinin, 1996) highlight the advantages of natural methods of forest restoration in their papers. However, there is some evidence that accelerated forest restoration by means of planting is effective. Papers by Kotov (1990), Nezabudkin (1971), Pchelin (1999), Romanov, Eremin \& Nureeva (2007, 2008a, 2008b, 2009, 2010, 2012), Eremin (2013), Kurbanov et al. (2011), Chernykh et al. (2009), Karaseva (2003, 2012), Nureeva et al. (2010), and Miftakhov (2011) provide information on productivity improvement of planted forests in the Middle Volga Region. Basic characteristics of forest growth conditions and the modes of forest management in pine forests are given in Table 2.

Active forest restoration by means of planting contributes to improvement in forest productivity as well as significantly increasing the total area of forests. According to the data of Romanov and his co-authors (2007, 2008a, 2008b, 2009, 2010, 2011, 2012), non-forested

Table 1 Comparison of the technologies for plantation establishment between the Middle Volga Region and Finland

\begin{tabular}{|c|c|c|}
\hline Action & Middle Volga Region & Finland \\
\hline Tillage & It is always carried out (scheme: ridge-forming $\rightarrow$ plough planting) & $\begin{array}{l}\text { It is obligatory both in case of natural and artificial } \\
\text { regeneration. With the exception of the land with } \\
\text { the poorest and the driest soil. }\end{array}$ \\
\hline Planting & $\begin{array}{l}\text { Density of planting of seedlings with bare roots - no less than } \\
5000-6000 \text { trees/ha, density of planting of seedlings with } \\
\text { container planting - } 2500-3000 \text { trees/ha }\end{array}$ & Planting seedlings in containers - 2000 trees/ha \\
\hline Sowing & $\begin{array}{l}\text { It is practically never used. It is sometimes used at the fire sites } \\
\text { (dry and fresh sandy soil) }\end{array}$ & Number of seed beds per hectare for pine is $4000-5000$ \\
\hline Planting material & $\begin{array}{l}\text { Seedlings with bare roots are mainly used. Since } 2000 \text {, seedlings } \\
\text { in containers are used in the Nizhniy Novgorod oblast, since } \\
\text { 2014_-in the Republic of Mari El }\end{array}$ & Planting seedlings in containers (almost 100 \%) \\
\hline
\end{tabular}




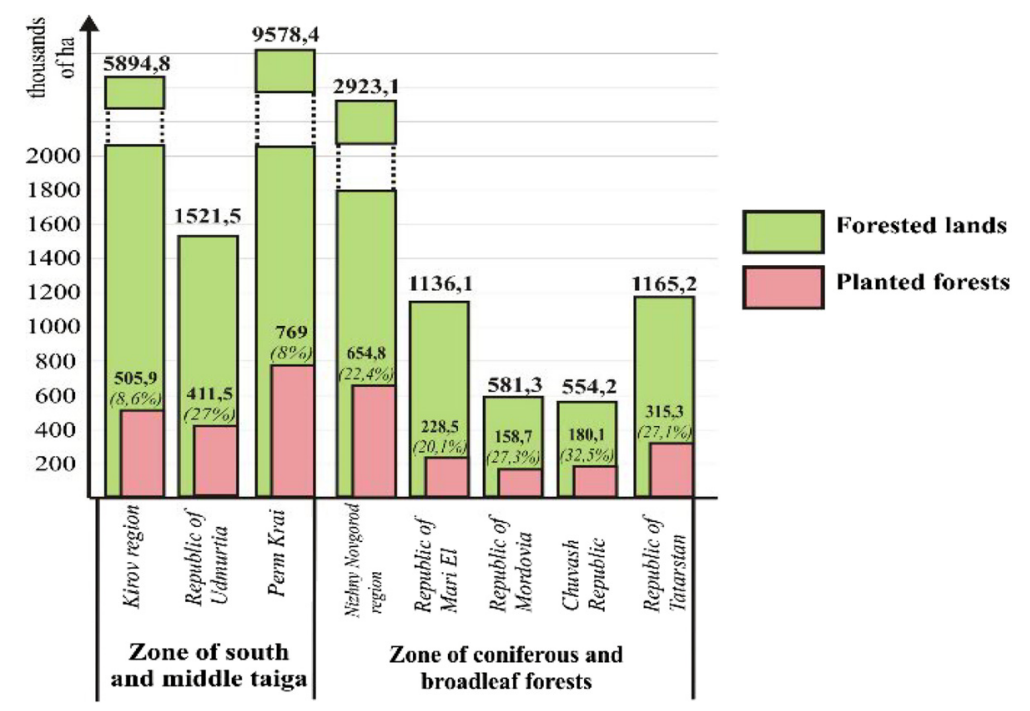

Fig. 3 Percentage of total forest land containing planted forests by republic or region within the Middle Volga Region (based on data from the (State Recording of Forest Fund for January 1, 2007) and reproduced from (Romanov, Nureeva \& Eremin 2013); commas are used instead of decimal points)

areas (clearings, fire sites etc.) have considerably reduced in the republics and oblasts of the Middle Volga Region during the period 1940-2007. For example, the nonforested area of the Nizhny Novgorod oblast has reduced 5.2 times, the Chuvash republic-17.3 times, the Republic of Tatarstan-12.2 times and the Republic of Mari El-23.7 times. Accelerated forest growth will provide good-quality timber in a short time frame, which in turn will help to alleviate issues around resource supply for pulp-and-paper plants and woodworking enterprises as well as protecting high-value natural boreal forests from felling. However, little, if any, quantitative information is available that compares the growth and yield of planted Scots pine stands with that of natural stands in the Middle Volga Region. Therefore, the aim of the study reported here was to develop growth and yield functions for Scots pine in natural and planted stands to enable such comparisons to be made then use these to manage growth.

\section{Methods}

\section{Stand information}

Inventory data from seven forests (with a combined area of more than 185,000 ha) located in the republics and oblasts of the Middle Volga Region were obtained (Table 3). These data were collected as part of forest inventories conducted every 10 years by the state board of forest management. Forests were divided into natural and planted forests based on interpretation of forest survey data for the years 2002-2004.

\section{Data collection and processing}

Standing volume data from 17,448 sites $^{2}$ containing natural and planted Scots pine forests, ranging in age from 10 up to 70 years, were used to develop a mathematical model for stand growth. From these data, mean values of stock, growing stock increment and growth class in 10-year cycles were determined. Data for Scots pine growing under four different growth

Table 2 Modes of forest management in Scots pine forests with due account of forest growth conditions (soddy podzolic soil)

\begin{tabular}{|c|c|c|c|c|c|}
\hline Forest growth conditions & Soil & $\begin{array}{l}\text { Recommended methods of } \\
\text { forest restoration }\end{array}$ & $\begin{array}{l}\text { Number of } \\
\text { thinning } \\
\text { operations }\end{array}$ & $\begin{array}{l}\text { Planting density } \\
\text { of Scots pine } \\
\text { (trees/ha) }\end{array}$ & $\begin{array}{l}\text { Harvest } \\
\text { age (years) }\end{array}$ \\
\hline$A_{1}$-dry coniferous forest & Dry sand & $\begin{array}{l}\text { Pine undergrowth conservation, bare } \\
\text { soil with conservation of seed bearers } \\
\text { (obligatory); planting and sowing in } \\
\text { the furrows }\end{array}$ & 3 & 8000 & $81-100$ \\
\hline $\mathrm{A}_{2}$ - fresh coniferous forest & Fresh sand & $\begin{array}{l}\text { Pine undergrowth conservation, bare } \\
\text { soil with conservation of seed bearers } \\
\text { (obligatory); planting in fire lines }\end{array}$ & $3-4$ & $5500-6000$ & $81-100$ \\
\hline $\begin{array}{l}\mathrm{B}_{2} \text {-fresh subor, i.e. mixed } \\
\text { pine forests with birch }\end{array}$ & $\begin{array}{l}\text { Fresh sandy loam } \\
(10-15 \% \text { loam })\end{array}$ & $\begin{array}{l}\text { Pine undergrowth conservation; pine } \\
\text { planting in the furrows and in fire lines }\end{array}$ & $3-4$ & $4000-6000$ & $81-100$ \\
\hline $\begin{array}{l}\text { C2-fresh suramen, i.e. mixed } \\
\text { spruce and deciduous forest }\end{array}$ & $\begin{array}{l}\text { Fresh clay loam } \\
\text { (20-40 \% loam) }\end{array}$ & $\begin{array}{l}\text { Pine undergrowth conservation; pine } \\
\text { planting in the furrows and in fire lines }\end{array}$ & $3-4$ & 4000 & $81-100$ \\
\hline
\end{tabular}


Table 3 Forest area by dominant species in the seven forests studied in the Middle Volga Region

\begin{tabular}{|c|c|c|c|c|c|c|c|c|c|}
\hline \multirow[t]{2}{*}{ Forest name } & \multirow[t]{2}{*}{ Location } & \multirow{2}{*}{$\begin{array}{l}\text { Total forested } \\
\text { area (ha) }\end{array}$} & \multicolumn{7}{|c|}{ Area of stands by dominant species (ha) } \\
\hline & & & $\begin{array}{l}\text { Scots } \\
\text { pine }\end{array}$ & $\begin{array}{l}\text { Norway } \\
\text { spruce }\end{array}$ & $\begin{array}{l}\text { Siberian } \\
\text { fir }\end{array}$ & $\begin{array}{l}\text { Common } \\
\text { oak }\end{array}$ & $\begin{array}{l}\text { Silver } \\
\text { birch }\end{array}$ & Aspen & $\begin{array}{l}\text { Other } \\
\text { species }\end{array}$ \\
\hline Scientific and Experimental & Republic of Mari El & 7102.7 & 2773.5 & 341.7 & 1.8 & 0.9 & 3299 & 182.4 & 503.4 \\
\hline Kokshayskoe & Republic of Mari El & 15432 & 8822.7 & 314.8 & No data & 664.7 & 3279.7 & 943.9 & 1400.6 \\
\hline Kuyarskoe & Republic of Mari El & 16491 & 7272 & 279 & 0 & 0 & 7755 & 317 & 868 \\
\hline Kadadinskoe & Penza oblast & 82138 & 42578 & 914 & 0 & 4136 & 15738 & 15309 & 3463 \\
\hline Agryzskoe & Republic of Tatarstan & 42466 & 13860 & 5997 & 193 & 841 & 7854 & 6292 & 7429 \\
\hline Voskresenskoe & Nizhny Novgorod oblast & 14208 & 10504 & 148 & 0 & 0 & 3349 & 123 & 84 \\
\hline Staroustinskoe & Nizhny Novgorod oblast & 7230 & 4720 & 393 & 0 & 111 & 1606 & 396 & 3 \\
\hline
\end{tabular}

The table provides the data obtained from the inventory of stands in the forest

conditions on soddy podzolic soil: dry and fresh lean sandy soil ( $A_{1}$ and $A_{2}$, respectively); fresh sandy loam $\left(10-15 \%\right.$ clay) soil $\left(B_{2}\right)$; and fresh clay loam $(20-$ $40 \%$ loam) soil $\left(\mathrm{C}_{2}\right)$ were used for the analysis (These growth conditions exist in all the forests studied), Table 2. The seven forest areas were chosen because pine forests are an important component of them, and those forests have large areas of planted pine forests. The forests were chosen in accordance with forest growth conditions which were common for the boreal forests. Mensuration characteristics (volume, growing stock increment) of the studied samples of Scots pine at these seven forest areas were determined using the standard Russian methods (Chernykh et al. 2006).

Determination of the main silvicultural indices for natural and planted stands and their comparative analysis was carried out using the methods of Romanov, Nureeva \& Eremin (2009). The first step of this analysis was to select the plots to be included on the basis of the proportion of Scots pine. Next, tabular summaries of parameters such as forest growth conditions, age, density, productivity, provenance of plantations and the share of Scots pine in the plantations were made. Area-weighted mean values for the parameters (share of pine, density, productivity) of the plantations were calculated for every 10 years. The characteristics of the planted forests of interest are shown in Table 4 and were determined as follows. The number of trees per hectare plus their diameter and height are the input data for calculating standing volume. The original number of trees per hectare was calculated using information from the relevant planting plans and data on the distance between the trees within a row and between rows. (Planting pattern was defined by measurement of the distance between the rows and the distance between the densest planted trees in a row for all the stands. No fewer than 20 measurements were made between the rows and within the row. Actual number of planted trees should not and could not coincide with the number of planted trees by the planted pattern.) Tree diameter at breast height $(1.3 \mathrm{~m})$ was measured using a pair of tree callipers, and total tree height was measured using a height indicator. Standing volume was calculated using specially designed tables that were drew up by Moiseev in 1971 (Chernykh et al. 2006).

Tree age was determined by counting the annual rings from an increment core collected at the root collar from 3-5 mean trees chosen in each plot. The current stand density was obtained from the results of a test plot and recalculation of the obtained data per hectare. Mensuration practices are very similar in Russia and Finland (Table 5).

Absolute stand density was calculated as the sum of the total basal area per hectare. Relative stand density was calculated by dividing absolute stand density by the total basal area of the normal growing stock with a relative stand density of 1.0. Growing stock increment was determined by dividing the standing volume of a stand by the age of that stand.

\section{Data analysis}

The relationship between total standing volume and stand age was modelled using the nonlinear asymptotic Mitscherlich function as shown in Eq. 1:

$$
\mathbf{Y}=\mathbf{K} *\{1-\exp [-\mathbf{a} * \mathbf{A}]\}^{\mathbf{b}}
$$

where $\mathbf{K}$ denotes the maximum growing stock, $\mathbf{A}$ denotes the 10-year age class and $\mathbf{a}$ and $\mathbf{b}$ define the form of the equation and show the growth rate of trees and their competitive stability or environmental resistance. Processing of the basic data from the seven sample areas was carried out using analysis of 
Table 4 Mean stand characteristics of Scots pine in seven selected forests of the Middle Volga Region (some data reproduced from Romanov, Nureeva \& Eremin 2013)

\begin{tabular}{|c|c|c|c|c|c|c|c|c|c|c|}
\hline Forest name & Location & $\begin{array}{l}\text { Age } \\
\text { (years) }\end{array}$ & $\begin{array}{l}\text { Planting density } \\
\text { (trees/ha) }\end{array}$ & $\begin{array}{l}\text { Relative stand } \\
\text { density }\end{array}$ & $\begin{array}{l}\text { Current stand } \\
\text { density (trees/ha) }\end{array}$ & $\begin{array}{l}\text { Diameter at breast } \\
\text { height }(\mathrm{cm})\end{array}$ & Height (m) & $\begin{array}{l}\text { Standing volume, } \\
\left(\mathrm{m}^{3} / \mathrm{ha}\right)\end{array}$ & $\begin{array}{l}\text { Mean annual increment } \\
\left(\mathrm{m}^{3} \mathrm{ha}^{-1} \text { year }^{-1}\right)\end{array}$ & Soil type \\
\hline $\begin{array}{l}\text { Scientific and } \\
\text { Experimental }\end{array}$ & Republic of Mari El & 58 & 13300 & 1.0 & 1245 & 19.0 & 20.4 & 324.0 & 5.6 & Sandy \\
\hline Kokshayskoe & Republic of Mari El & 36 & 13300 & 1.0 & 3900 & 9.6 & 15.4 & 247.7 & 6.9 & Sandy \\
\hline Kuyarskoe & Republic of Mari El & 36 & 10000 & 0.9 & 2160 & 11.9 & 12.8 & 210.5 & 5.8 & Sandy \\
\hline Kadadinskoe & Penzenskaya oblast & 16 & 8000 & 1.0 & 5700 & 7.1 & 8.0 & 88.4 & 5.5 & Light loam \\
\hline Agryzskoe & Republic of Tatarstan & 37 & 4250 & 1.0 & 935 & 21.6 & 20.0 & 322.0 & 8.7 & Light loam \\
\hline Voskresenskoe & $\begin{array}{l}\text { Nizhny Novgorod } \\
\text { oblast }\end{array}$ & 41 & 4700 & 0.7 & 1095 & 16.0 & 15.0 & 160.0 & 3.9 & Sandy \\
\hline Staroustinskoe & $\begin{array}{l}\text { Nizhny Novgorod } \\
\text { oblast }\end{array}$ & 33 & 4700 & 0.7 & 1600 & 12.0 & 11.0 & 110.0 & 3.3 & Sandy \\
\hline
\end{tabular}

The table provides the data obtained from the sample plot 
Table 5 Comparison of methods for calculating mean forest taxation indices of stands between Russia and Finland

\begin{tabular}{|c|c|c|c|}
\hline \multirow[t]{2}{*}{ Forest taxation indices } & \multirow{2}{*}{$\begin{array}{l}\text { Unit of } \\
\text { measurement }\end{array}$} & \multicolumn{2}{|l|}{ Methods used for calculation of mean forest taxation indices } \\
\hline & & Russia (on approval of forest management instruction, 2011) & Finland (Pykalainen and Kurttila 2009) \\
\hline $\begin{array}{l}\text { Basic unit for forest } \\
\text { management }\end{array}$ & & Site & Site \\
\hline Area of stratum & ha & From 0.5 & $0.5-2.0$ \\
\hline Mean diameter $(\mathrm{d})^{\mathrm{a}}$ & $\mathrm{cm}$ & $\begin{array}{l}\text { Empirical measurements of diameters at a height } \\
\text { of } 1.3 \mathrm{~m} \text {. It is calculated as the quadratic average }\end{array}$ & $\begin{array}{l}\text { Empirical measurements of diameters } \\
\text { at the height } 1,3 \mathrm{~m}\end{array}$ \\
\hline Mean height (h) & $\mathrm{m}$ & $\begin{array}{l}\text { Empirical measurements of height of 3-5 mean } \\
\text { trees with each class diameter }\end{array}$ & $\begin{array}{l}\text { Empirical measurements of height of } \\
3 \text { mean trees }\end{array}$ \\
\hline Relative density $(p)$ & & $\begin{array}{l}\text { Total basal area per ha of stands relative to the } \\
\text { total basal area of a normal stand }(p=1) \text {, derived } \\
\text { from the yield table for the considered area }\end{array}$ & Not used \\
\hline $\begin{array}{l}\text { Sum of basal area in the } \\
\text { stand }\end{array}$ & $\mathrm{m}^{2} / \mathrm{ha}$ & Measured with Bitterlich's angle gauge & Measured with Bitterlich's angle gauge \\
\hline Age of stand & years & $\begin{array}{l}\text { Count of annual rings from an increment core collected } \\
\text { at the root collar ( } 3-5 \text { mean trees are chosen) }\end{array}$ & Calculation of annual rings of mean trees \\
\hline Number of trees & trees/ha & Use of the inventory data at a sample area & Use of the inventory data at a sample area \\
\hline Stand composition & $\%$ & $\begin{array}{l}\text { By the share of the tree species volume in the total } \\
\text { stand volume }\end{array}$ & $\begin{array}{l}\text { By the share of the tree species volume in } \\
\text { the total stand volume }\end{array}$ \\
\hline Stand volume & $\mathrm{m}^{3} / \mathrm{ha}$ & $\begin{array}{l}\text { Use of the tables; input data in the tables are the } \\
\text { sum of basal area of trees in a stand and mean height }\end{array}$ & $\begin{array}{l}\text { Use of the tables; input data in the tables } \\
\text { are the sum of basal area of trees in a stand } \\
\text { and mean height }\end{array}$ \\
\hline
\end{tabular}

${ }^{\mathrm{a}}$ Maximum allowable measurement error is $\pm 5 \%$

variance. Goodness of fit was assessed via the coefficient of determination $\left(R^{2}\right)$.

\section{Results and discussion}

The calculated values of actual and standard stocks of planted or natural pine trees at the age of 100 years from seven forest areas with different soil types are shown in
Table 6. In most cases, the productivity for 100-year-old trees $\left(M_{100}\right)$ is higher for planted stands than for natural stands. The growth of stock also depends on soil quality. The data collected for the seven forests studied (which are for forests located in the zone of mixed coniferousbroad leaved forest of the Middle Volga Region) show the advantages of planted forest in terms of growth rate

Table 6 Estimates of model parameters and goodness of fit statistics for the relationship between growing stock and stand age for planted and natural Scots pine stands growing on different site types (data reproduced from Romanov, Nureeva \& Eremin 2013)

\begin{tabular}{|c|c|c|c|c|c|c|c|c|c|}
\hline \multirow[t]{2}{*}{ Origin } & \multirow[t]{2}{*}{ Parameter } & \multicolumn{4}{|c|}{ Actual stock } & \multicolumn{4}{|c|}{ Standard stock } \\
\hline & & $A_{1}$ & $A_{2}$ & $\mathrm{~B}_{2}$ & $C_{2}$ & $A_{1}$ & $A_{2}$ & $\mathrm{~B}_{2}$ & $C_{2}$ \\
\hline \multirow[t]{6}{*}{ Planted } & Number of forest sites & 2206 & 3892 & 1423 & 9927 & 2206 & 3892 & 1423 & 9927 \\
\hline & K & 216 & 311 & 400 & 318 & 409 & 520 & 593 & 573 \\
\hline & a & 4.94 & 4.32 & 3.5 & 5.55 & 3.11 & 3.08 & 2.9 & 3.59 \\
\hline & $b$ & 3.5 & 3.34 & 2.53 & 3.23 & 2.47 & 2.56 & 2.21 & 2.41 \\
\hline & $M_{100}{ }^{a}, \mathrm{~m}^{3}$ & 211 & 297 & 370 & 315 & 365 & 461 & 524 & 535 \\
\hline & $R^{2}$ & 0.844 & 0.907 & 0.922 & 0.878 & 0.907 & 0.953 & 0.953 & 0.954 \\
\hline \multirow[t]{6}{*}{ Natural } & Number of forest sites & 736 & 4701 & 2717 & 2088 & 736 & 4701 & 2717 & 2088 \\
\hline & K & 215 & 248 & 270 & 304 & 419 & 426 & 462 & 518 \\
\hline & $a$ & 5.75 & 9.14 & 8.96 & 4.3 & 3.41 & 5.4 & 4.68 & 3.23 \\
\hline & $b$ & 5.59 & 15.97 & 11.51 & 2.87 & 2.8 & 5.2 & 3.51 & 2.35 \\
\hline & $M_{100}, \mathrm{~m}^{3}$ & 211 & 248 & 248 & 292 & 382 & 416 & 447 & 471 \\
\hline & $R^{2}$ & 0.835 & 0.715 & 0.663 & 0.688 & 0.929 & 0.905 & 0.862 & 0.829 \\
\hline
\end{tabular}

The actual stock is the true mean stock volume with relative density from 0.5 to 0.9 . The standard stock is the calculated stock for plantations with relative density 1.0. The timber lands were chosen from the seven forests listed in Tables 3, 4, 7 and 8

${ }^{\mathrm{a}} M_{100}$-the productivity for 100 -year-old stands. $M_{100}$ (years) is a calculated for the plantations in the age of 100-year stock 
and stock growth compared with natural forests. These data were combined and graphed in Fig. 4. The advantages of growing planted forests highlighted by these data are not widely known but can be used to improve the annual growth of trees to obtain more timber in shorter time periods.

The mean silvicultural characteristics of two age groups ( $<20$ years and $21-50$ years) of standing timber were studied in more detail through examination of Russian legal documents in force during different periods of forest regeneration (Tables 7 and 8). The two age groups differ in initial stand density: fewer than 5000 trees/ha for the stands less than 20 years old and 6000 trees/ha or even more for the stands $21-50$ years old (Tables 7 and 8). Analysis of the proportion of Scots pine in the seven forests studied show that it is not always the main species in plantations under the age of 20 years in forest growth conditions $\mathrm{A}_{2}$ (Table 7). The proportion of Scots pine was higher in planted than in natural stands for five of the seven forests studied ( $<20$-year-old forests). In the case of the 21-50-year-old plantations, there was more Scots pine than other species in planted stands in all forests studied except for Voskresenskoe forest in the Nizhny Novgorod oblast. The proportion of planted Scots pine is higher than the proportion of natural Scots pine in pine forests with sandy soils $\left(\mathrm{A}_{2}\right)$. These sites are located in the Scientific and Experimental, Kuyarskoe and Kokshayskoe forests areas of Mari El Republic, Agryzskoe forestry of Tatarstan Republic, Kadadinskoe forestry of the Penza region and the Voskresenskoe and Staroustinskoe forests of the Nizhny Novgorod region.

Relative stand density of planted pines was higher than that of natural pines in six of seven forests studied. The Voskresenskoe forest was the only exception (Tables 7 and 8). Mean forest density in Kokshayskiy forest (up to 20 years old) and Voskresenskiy forest
(21-50 years) is the same as in planted and natural forests. Planted pine forests generally have a higher relative stand density than natural forests due to a combination of high plant density and natural regeneration.

Mean quality class of planted pine stands was higher in two forests studied (Research and Experimental forest and Agryzskoe forest, age group-up to 20 years (Table 7)). For the age range of 21-50, mean quality class of planted pine forests is higher in three forests studied-Research and Experimental forest, Kuyarskoe forest and Agryzskoe forest (Table 8). In Kadadinskoe, Voskresenskoe and Staroustinskoe forests, this parameter is the same as in planted as in natural forests. Quality class of planted Scots pine is not always higher in comparison with natural stands, however. It can be explained by higher stocking density of plantations due to high density of planting. At the age range of $21-50$ years, there is a higher proportion of Scots pine in all the studied planted forests, except Voskresenskoe forest. Mensuration characteristics are higher in Kuyarskiy and Kokshayskiy forests only (plantations up to 20 years). This phenomenon can be explained by the predominance of sandy soil in the area where Scots pine has no competitors. Calculated total volume per hectare for 15- and 35-year-old trees was higher in all the forests except for Voskresenskoe forest and Staroustinskoe forest. Scots pine standing volume is higher in all the forests except Scientific and Experimental forest (15 years old), Agryzskoe forest (15 years old) and Voskresenskoe forest (15 and 35 years old). Thus, mean volume of Scots pine stands in planted forests (35 years old) is higher than in natural forests by a factor of 2.7 in Scientific and Experimental forest, 1.25 in Kokshayskoe forest, 1.45 in Kuyarskoe forest, 1.11 in Kadadinskoe forest, 2.86 in Agryzskoe forest and 2.29 in Staroustinskoe forest. Some of the mensuration characteristics shown in the Voskresenskoe forest are due to a lack of tending,

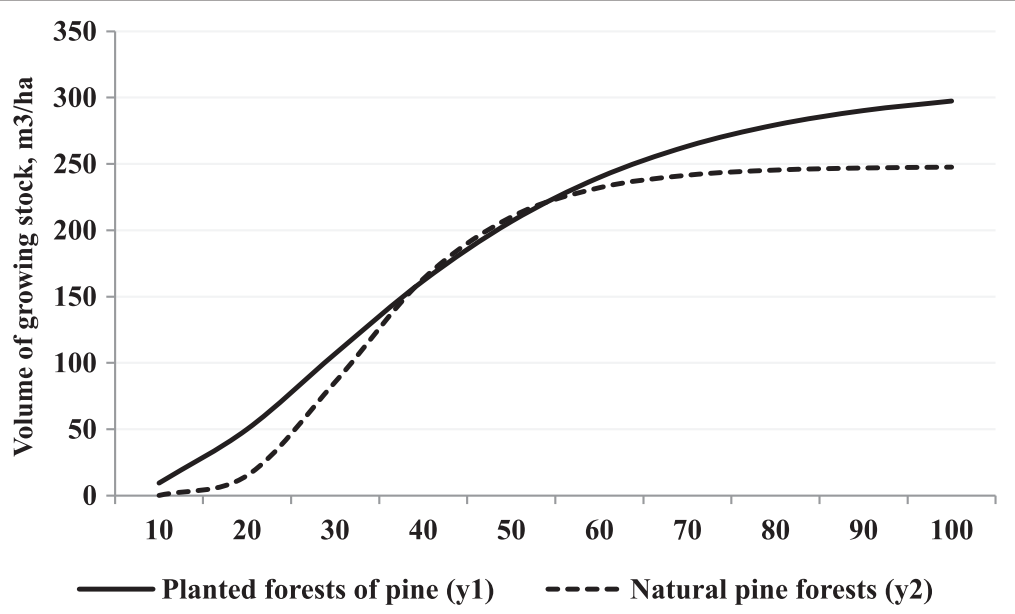

Fig. 4 The growing stock of wood in the natural and planted Scots Pine forests on the sandy soil 
Table 7 Mean forest valuation characteristics for Scots pine plantations up to 20 years old growing in a sandy soil $\left(A_{2}\right)$

\begin{tabular}{|c|c|c|c|c|c|c|c|c|c|}
\hline \multirow[t]{3}{*}{ Forest name } & \multirow[t]{3}{*}{ Origin } & \multirow[t]{3}{*}{ Area (ha) } & \multicolumn{5}{|c|}{ Mean values at mean age } & \multicolumn{2}{|c|}{$\begin{array}{l}\text { Mean growing stock for } 15 \text {-year-old } \\
\text { stands }\left(\mathrm{m}^{3} / \mathrm{ha}\right)\end{array}$} \\
\hline & & & \multirow{2}{*}{$\begin{array}{l}\text { Growing stock } \\
\left(\mathrm{m}^{3} / \mathrm{ha}\right)\end{array}$} & \multirow[t]{2}{*}{ Age (years) } & \multirow{2}{*}{$\begin{array}{l}\text { Proportion } \\
\text { of Scots } \\
\text { pine (\%) }\end{array}$} & \multirow{2}{*}{$\begin{array}{l}\text { Relative } \\
\text { density }\end{array}$} & \multirow{2}{*}{$\begin{array}{l}\text { Quality } \\
\text { class }\end{array}$} & & \\
\hline & & & & & & & & Total & Scots pine \\
\hline \multirow[t]{2}{*}{ Scientific and experimental } & Natural & 4.1 & 27.1 & 11.6 & 79 & 0.56 & 2.0 & 40.0 & 40.0 \\
\hline & Planted & 153.6 & 59.0 & 15.3 & 71 & 0.74 & 1.5 & 51.6 & 26.6 \\
\hline \multirow[t]{2}{*}{ Kokshayskoe } & Natural & 14.8 & 25.2 & 12.3 & 65 & 0.71 & 1.7 & 30.7 & 20.0 \\
\hline & Planted & 120.8 & 34.7 & 13.4 & 76 & 0.71 & 1.8 & 38.8 & 29.5 \\
\hline \multirow[t]{2}{*}{ Kuyarskoe } & Natural & 44.7 & 15.8 & 8.1 & 64 & 0.60 & 1.7 & 29.2 & 18.7 \\
\hline & Planted & 83.6 & 34.2 & 14.2 & 80 & 0.80 & 2.0 & 36.1 & 28.9 \\
\hline \multirow[t]{2}{*}{ Kadadinskoe } & Natural & 2.5 & 20.1 & 11.6 & 70 & 0.60 & 1.2 & 25.9 & 18.1 \\
\hline & Planted & 35.7 & 45.0 & 19.3 & 64 & 0.65 & 1.8 & 35.0 & 22.4 \\
\hline \multirow[t]{2}{*}{ Agryzskoe } & Natural & 4.1 & 27.1 & 11.6 & 79 & 0.56 & 2.0 & 40.0 & 40.0 \\
\hline & Planted & 153.6 & 59.0 & 15.3 & 71 & 0.74 & 1.5 & 51.6 & 26.6 \\
\hline \multirow[t]{2}{*}{ Voskresenskoe } & Natural & 40.8 & 24.5 & 11.6 & 72 & 0.60 & 2.5 & 31.7 & 22.8 \\
\hline & Planted & 210.7 & 16.9 & 14.3 & 40 & 0.61 & 2.7 & 17.7 & 7.1 \\
\hline \multirow[t]{2}{*}{ Staroustinskoe } & Natural & 3.2 & 11.3 & 12.5 & 96 & 0.76 & 2.0 & 13.6 & 13.0 \\
\hline & Planted & 6.0 & 33.7 & 13.0 & 70 & 0.83 & 2.5 & 38.9 & 27.2 \\
\hline
\end{tabular}

The mean square values of mensuration characteristics and age of the stands provided in the table are obtained from the forest inventory

which is caused by insufficient local workforce to manage the forests.

Despite the fact that mean quality class of planted Scots pine stands in most forests studied is lower than natural forests, their productive capacity and stock growth is higher. It is typical for young growth $(<20$ years) and also for older artificial stands, planted with higher starting density. Higher productivity of planted forests in comparison with natural stands is explained by the following factors: (1) use of the type of tillage, which contributes to improvement of soil agrophysical properties and intensification of planted forests growth; (2) regulation of density and spatial distribution of trees in order to reduce competition for light and nutrient during the first years of

Table 8 Forest valuation characteristics for 21-50-year-old Scots pine plantations growing in sandy soil (A2)

\begin{tabular}{|c|c|c|c|c|c|c|c|c|c|}
\hline \multirow[t]{3}{*}{ Forest name } & \multirow[t]{3}{*}{ Origin } & \multirow[t]{3}{*}{ Area (ha) } & \multicolumn{5}{|c|}{ Mean values at given age } & \multicolumn{2}{|c|}{$\begin{array}{l}\text { Mean growing stock for } \\
35 \text {-year-old stands }\left(\mathrm{m}^{3} / \mathrm{ha}\right)\end{array}$} \\
\hline & & & \multirow{2}{*}{$\begin{array}{l}\text { Growing stock } \\
\left(\mathrm{m}^{3} / \mathrm{ha}\right)\end{array}$} & \multirow{2}{*}{$\begin{array}{l}\text { Age } \\
\text { (years) }\end{array}$} & \multirow{2}{*}{$\begin{array}{l}\text { Proportion of } \\
\text { Scots pine (\%) }\end{array}$} & \multirow{2}{*}{$\begin{array}{l}\text { Relative } \\
\text { density }\end{array}$} & \multirow{2}{*}{$\begin{array}{l}\text { Quality } \\
\text { class }\end{array}$} & & \\
\hline & & & & & & & & Total & Scots pine \\
\hline \multirow[t]{2}{*}{ Scientific and experimental } & Natural & 23.4 & 38.5 & 32.9 & 73 & 0.63 & 3.6 & 41.0 & 29.9 \\
\hline & Planted & 376.4 & 90.1 & 33.5 & 85 & 0.67 & 1.7 & 94.1 & 80.0 \\
\hline \multirow[t]{2}{*}{ Kokshayskoe } & Natural & 611.7 & 117.3 & 31.7 & 79 & 0.67 & 1.4 & 129.5 & 102.3 \\
\hline & Planted & 3022 & 137.7 & 34.7 & 92 & 0.75 & 1.5 & 138.9 & 127.8 \\
\hline \multirow[t]{2}{*}{ Kuyarskoe } & Natural & 47.5 & 96.91 & 34.2 & 76 & 0.59 & 2.2 & 99.2 & 75.4 \\
\hline & Planted & 1220.3 & 103.81 & 30.4 & 92 & 0.88 & 2.0 & 119.5 & 110.0 \\
\hline \multirow[t]{2}{*}{ Kadadinskoe } & Natural & 15.5 & 196.1 & 44.3 & 89 & 0.72 & 1.4 & 154.9 & 137.9 \\
\hline & Planted & 202.3 & 218.7 & 44.9 & 90 & 0.82 & 1.4 & 170.5 & 153.4 \\
\hline \multirow[t]{2}{*}{ Agryzskoe } & Natural & 22.54 & 158.6 & 41.5 & 80 & 0.70 & 1.9 & 110.0 & 44.0 \\
\hline & Planted & 998.5 & 157.4 & 34.8 & 87 & 0.80 & 1.5 & 138.9 & 126.0 \\
\hline \multirow[t]{2}{*}{ Voskresenskoe } & Natural & 96.2 & 86.8 & 33.5 & 71 & 0.69 & 2.4 & 90.7 & 64.4 \\
\hline & Planted & 2354.4 & 66.8 & 31.1 & 65 & 0.65 & 2.4 & 75.2 & 48.9 \\
\hline \multirow[t]{2}{*}{ Staroustinskoe } & Natural & 5.8 & 189.7 & 45.0 & 20 & 0.60 & 2.0 & 147.5 & 29.5 \\
\hline & Planted & 11.6 & 70.4 & 28.8 & 79 & 0.60 & 2.0 & 85.6 & 67.6 \\
\hline
\end{tabular}


growth. Such conditions make it possible for planted trees to grow quickly in subsequent years; and (3) choice of optimum conditions of cultivation along with a decrease of intra-population and inter-species competition by implementing a number of agrotechnical and silvicultural measures.

Calculation of actual mean stand increment with the use of data from seven forests of republics and oblasts of the Middle Volga Region demonstrates the potential for accelerated growth of planted forest in comparison with natural forests. However, a lack of control over planted trees during the entire growing period sets them equal to natural stands. Even so, accelerated growth rates of planted forests have been obtained practice (data of artificial forest reproduction). Thus, growing stock increment of planted pine forests is 9-63\% higher than growing stock increment of natural pine forests (Table 9). In the future, a monitoring system should be implemented at the time of planting seedlings in un-forested areas and should be continued throughout the entire rotation for all the levels of management.

Stand increment of planted Scots pine forests may be improved by utilising productive land with favourable growth conditions. A particular feature planted Scots pine forests is a high starting density, which varies from 4300 to 13,300 trees/ha. Annual growing stock increment of planted Scots pine forests varies from 3.3 to $8.7 \mathrm{~m}^{3} \mathrm{ha}^{-1}$ year $^{-1}$ (Table 4).

A high stand density should favour canopy closure of the host species, reduction of stems with knots and more intensive height growth. Thus, expenditure on planted forest cultivation should include not only activities preceding planting of trees but also thinning. It is important to include into costs of planted forest cultivation both pre-planting cultivation and thinning. Thinning of 30-40-year-old plantations performs two tasks: (1) obtaining profit through the use of tree biomass in the pulp-and-paper industry, electricity sector and other spheres of industry; and (2) achieving additional growth of trees due to more light.

Planted forests are also of better timber and mensuration characteristics than natural forests. Thus, for example, the annual yield from planted forests yield is 5.6 to $9.2 \mathrm{~m}^{3}$ per hectare, with higher yields leading to shorter rotations.

\section{Conclusions}

In conclusion, it is important to note that a long practice of planting forests in the Middle Volga Region (more than 100 years) may be a basis for development of standards in engineering and cultivation of planted forests. The Middle Volga Region may be an investment-attractive region for establishment of large timber complexes with complete production cycle as it is the region with high population density (in comparison with other parts of Russia), intensive wood consumption and vast forest plantations. Besides, intensive ways of forest restoration by means of establishment of plantations shall contribute to conservation of Russian natural boreal forests and improvement of ecology not only in Russia but throughout the northern hemisphere.

\section{Endnotes}

${ }^{1}$ Oblast and republic is a unit of federal division in Russia.

${ }^{2}$ The 17,448 sites are forest strata. A forest stratum is defined as an area of land that has similar soil conditions, and qualitative and quantitative characteristics of growing vegetation. Variability of growing vegetation in a forest stratum is within normative standards in which it is possible to carry out one and the same actions in protection, conservation and reproduction of forests in the territory of the forest stratum.

Table 9 The role of planted stands in increasing actual mean stock increment of Scots pine. (Source: state forest inventory materials of forests)

\begin{tabular}{|c|c|c|c|c|c|c|c|c|c|}
\hline \multirow[t]{4}{*}{ Forest name } & \multirow[t]{4}{*}{ Location } & \multicolumn{8}{|c|}{ Mean annual increment of standing volume $\left(\mathrm{m}^{3} \mathrm{ha}^{-1}\right.$ year $\left.^{-1}\right)$} \\
\hline & & \multicolumn{4}{|c|}{ All stands } & \multicolumn{4}{|c|}{ Stands $<70$ years old } \\
\hline & & \multirow[t]{2}{*}{ Natural } & \multirow[t]{2}{*}{ Planted } & \multicolumn{2}{|l|}{ Difference } & \multirow[t]{2}{*}{ Natural } & \multirow[t]{2}{*}{ Planted } & \multicolumn{2}{|l|}{ Difference } \\
\hline & & & & Absolute & Percentage & & & Absolute & Percentage \\
\hline Voskresenskoe & Nizhny Novgorod oblast & 3.20 & 3.49 & 0.29 & 8.9 & 3.41 & 3.49 & 0.08 & 2.1 \\
\hline Staroustinskoe & Nizhny Novgorod oblast & 3.42 & 5.59 & 2.17 & 63.3 & 4.53 & 5.62 & 1.08 & 23.9 \\
\hline Agryzskoe & Republic of Tatarstan & 3.92 & 5.09 & 1.17 & 29.8 & 4.43 & 5.16 & 0.73 & 16.6 \\
\hline Scientific and experimental & Republic of Mari El & 3.10 & 3.40 & 0.30 & 9.7 & 3.31 & 3.47 & 0.16 & 4.7 \\
\hline Kokshayskoe & Republic of Mari El & 3.11 & 3.57 & 0.46 & 14.8 & 3.58 & 5.04 & 1.46 & 40.9 \\
\hline Kuyarskoe & Republic of Mari El & 3.06 & 3.67 & 0.62 & 20.2 & 3.54 & 3.67 & 0.13 & 3.7 \\
\hline Kadadinskoe & Penzenskaya oblast & 3.53 & 4.41 & 0.88 & 24.84 & 4.37 & 4.46 & 0.09 & 2.12 \\
\hline
\end{tabular}




\section{Acknowledgements}

The work is accomplished within the Program of Strategic Development of State Educational Institutions of Higher Vocational Education for 2012-2014 years, as well as within the federal target-oriented program "Research and Academic Personnel of Russia" for 2009-2013 years in the project "Development and Study of Regional Agro-Silvicultural Bioenergetic Complexes". We express our deep appreciation to the translators Shalagina Marina and Nureeva Regina for a detailed translation of the manuscripts and for constructive comments from the reviewers and journal editors. We are especially grateful to the colleagues and candidates of the department of artificial crops, selection and biotechnologies of Volga State Technical University for gathering and processing of experimental data.

This study is based on a paper presented at the Third International Congress on Planted Forests, Bordeaux, May 2013.

\section{Authors' contributions}

The authors made equal contribution to preparation of the article. All authors read and approved the final manuscript.

\section{Competing interests}

The authors declare that they have no competing interests.

Received: 23 January 2015 Accepted: 28 April 2016

Published online: 07 June 2016

\section{References}

Chernykh, V. L., Domrachev, A. A., Elsukov, A. S., Kiseleva, N. G., \& Okhotin, N. N. (2009). Stand Assortment Table for Pine Plantations Estimation in the Volga Region. Vestnik of Altai State Agrarian University, 4(54), 35-41.

Chernykh, V. L., Verkhunov, A. V., Popova, A. V., \& Bazhin, O. N. (2006). Forest Inventory. Referenced data. Study Guide for the Students of the Specialties "Forestry", "Park and Landscape Engineering". Yoshkar-Ola: Mari State Technical University.

Demakov, Yu, P., Smykov, A. E., \& Denisov, S. A. (2008). Spacial structure of the forest fund of the Republic of Mari El. Vestnik of MarSTU Series Forest. Ecology. Nature Management, 1, 3-18.

Denisov, A. K. (1984). Natural forest restoration - profound analysis and assistance. Lesnoe khozyaystvo, 11, 21-23.

Denisov, S. A., Demicheva, N. V., \& Egorov, V. M. (2011). To chosing reforestation methods for pine forests of Penza Region. Search of the best way of pine forest restoration in Penza oblast. Izvestiya Vuzov. (Journal of Forestry Research), 1, 32-34. http://lesnoizhurnal.narfu.ru/upload/iblock/674/jagg6.pdf.

Denisov, S. A., Uspenskiy, E. I., \& Kalinin, K. K. (2002). Natural regeneration under forest canopy the cover in the Middle Volga Region. Izvestiya Vuzov (Journal of Forestry Research), 4, 46-53. http://lesnoizhurnal.narfu.ru/upload/iblock/3f1/ 3f1771f1ad1166d80dda5a04d372c279.pdf.

Eremin, N. V. (2013). Accelerated Forest Restoration and Forest Cultivation on the Example of Spruce Regeneration. Yoshkar-Ola: Volga State University of Technology.

Kalinin, K. K. (1996). Forest formation processes after fire in the Volga region. In J. G. Goldammer \& V. V. Furyaev (Eds.), Fire in ecosystems of boreal Eurasia (pp. 404-408). Dordrecht, Netherlands: Springer Science+Business Media.

Karaseva, M. A. (2003). Siberian larch in the Middle Volga: Scientific publication. Yoshkar-Ola: Mari State Technical University MarSTU.

Karaseva, M. A., \& Lezhnin, K. T. (2012). Use of Ameliorants in Pine Plantations Cultivation: Monograph. Yoshkar-Ola: Mari State Technical University.

Kotov, MM (1990) Forest Management Problems in the Middle Volga in Connection with Water Protection Function of Forests. Management in Riverian Forests: Head-Notes of the Report at the All-Russian Scientific Meeting (July 26-28, 1990 r). Moscow, 15-16.

Kurbanov, E. A., Nureeva, T. V., et al. (2011). Remote Monitoring of Dynamics of Forest Cover Problems, Reafforestation and Regeneration in Mari Forests. Vestnik of MarSTU, 3, 23-30.

Miftakhov, T. F., \& Nureeva, T. V. (2011). Ecological and economic grounding in favour of artificial plantations cultivation in relatively dry suramen for production of timber with necessary quality (Forest ecosystems in climate change conditions: biological productivity and remote monitoring. Materials of International Research and Practice Seminar, p. 190) (pp. 122-126). YoshkarOla: MarSTU.

Nezabudkin, G. K. (1971). Inspection and research of planted forests. Yoshkar-Ola: Mari State Technical University.
Nureeva, T. V., Miftakhov, T. F., \& Eremin, N. V. (2010). Accelerated Cultivation of Scots Pines and Arguments for Plantations Establishment on the Example of Arskoe Forestry of the Republic of Tatarstan (Forest Ecosystems in Climate Change Conditions: Biological Productivity, Monitoring and Adaptive Technologies. Materials of International Conference for Young Researches with the Elements of Scientific School, p. 275). Yoshkar-Ola: Mari State Technical University. http://csfm.marstu.net/publications.html. Accessed 25 Jan 2016.

Olsson, R., \& Air Pollution \& Climate Secretariat, \& Taiga Rescue Network. (2009). Boreal Forest and Climate Change. Air Pollution and Climate Series, 23. Göteborg, Sweden: AirClim. Retrieved 27 September 2015 from: http://www.wwf.ru/data/forests/for-clim/apc23_borealforest.pdf.

Order of the Federal Agency for Forestry Affairs. (2011). No. 516. On Approval of Forest Management Instruction. Moscow: http://www.roslesinforg.ru/ documents/fagency/0

Pchelin, V. I. (1999). Experience and Perspectives of Planted Forests Cultivation in the Middle Volga. Present-Day Problems for New Forests Planting in the Middle Volga. Materials of Regional Workshop Conference, Dedicated to the $100^{\text {th }}$ Anniversary of Gavriil Kuzmich Nezabudkin (pp. 98-99). Yoshkar-Ola: MarSTU.

Pykalainen, J., \& Kurttila, M. (2009). Development of forest planning in Finland: Methods and experience. Finnish Forest Research Institute. Metla. Joensuu, 2009.Tutkimusretkelle metsään. Perusaste. URL: http://www.metla.fi/julkaisut/ muut/opetuspaketti/tutkimusretkelle.pdf. Accessed 27 Sep 2015

Romanov, E. M., Eremin, N. V., \& Nureeva, T. V. (2007). Present-day state and problems of forest regeneration in Russia. Vestnik of Mari State Technical University Series Forest. Ecology. Nature Management, 1, 5-14.

Romanov, E. M., Eremin, N. V., \& Nureeva, T. V. (2008a). State and results improvement of artificial reafforestation in Nizhny Novgorod oblast. Vestnik of Mari State Technical University Series Forest. Ecology. Nature Management, 3(4), 18-29.

Romanov, E. M., Eremin, N. V., \& Nureeva, T. V. (2008b). Artificially forest reproduction: monitoring and improvement of efficiency. Lesnoe khozyaystvo, 1, 31-33.

Romanov, E. M., Eremin, N. V., \& Nureeva, T. V. (2009). State of forests reproduction in the Middle Volga Region. International cooperation in forest sector: balance of education, science and industry. Materials of International Conference (June 3-5, 2009, Yoshkar-Ola) (pp. 45-51). Yoshkar-Ola: MarSTU.

Romanov, E. M., Eremin, N. V., \& Nureeva, T. V. (2010). From artificial stands to plantations: expediency and silvicultural and economic profit. Lesnoe khozyaystvo, (6), 30-33.

Romanov, E. M., Eremin, N. V. Nureeva, T. V. (2011) Criteria and characteristics for conversion from artificial stands to plantations. Materials of Saint-Petersburg Research Institute of Forestry. Saint-Petersburg, Issue 1 (24), Part 1, 267.

Romanov, E. M., Eremin, N. V., \& Nureeva, T. V. (2012). Criteria and characteristics for conversion from artificial stands to the fund of accelerated planted forest cultivation. Izvestiya Vuzov (Journal of Forestry Research), 5, 5-11.

Romanov, E. M., Eremin, N. V., Nureeva, T. V., \& Mamaev, A. A. (2008). Importance of plantations in forests reproduction in the Republic of Mari El. Temporary problems of theory and practice of forestry (All-Russian Workshop Conference Dedicated to the 100 Anniversary of Doctor of Biological Sciences, Professor M.D. Danilov: Collected Works, pp. 68-73). Yoshkar-Ola: MarSTU.

Romanov, E. M., Nureeva, T. V., \& Eremin, N. V. (2013). Artificial forest regeneration in the Middle Volga: present day situation and problems to be solved. Vestnik of Mari State Technical University. Series Forest. Ecology. Nature Management, 3(19), 5-19. http://journals.volgatech.net/index.php/forest/article/view/118/133

Sennov, S. N. (1999). Results of 60 years of supervisions under natural forest growth. Saint-Petersburg: Saint-Petersburg Forestry Research Institute.

State Recording of Forest Fund. (2007). Moscow LLC «Ekoservis». 